\title{
Students' Creativity After Joining Advanced Design Class by Applying Portfolio
}

\author{
Sicilia Sawitri ${ }^{*}$, Wulansari Prasetyaningtyas ${ }^{2}$, Rodia Syamwil ${ }^{3}$ \\ Taofan Ali Achmadi ${ }^{4}$, Partini $^{5}$, Nur Qurota Ainina ${ }^{6}$ \\ 1,2,3,4,5,6 Universitas Negeri Semarang \\ *Corresponding author, E-mail: sicilia.sawitri@mail.unnes.ac.id
}

\begin{abstract}
Become a fashion designer, needs talent, creativity, and drawing skill. Each person has talent and creativity which brought when she/he was born, while skills can be obtained at school, in the community, from social media, and other. Creativity is an ability possessed by students with different levels. Increased creativity can be driven by an assessment model that gives students freedom to collect their work, through portfolios that are used as evaluation tools. Fashion Education Study program is one of the institution which offer some course to prepare someone to become a fashion designer, beside teacher at vocational school. The aim of this study was to know the students' creativity after they joint Advanced Design Class, by applying portfolio as evaluation instrument. By using quasi-experimental, one-shot group design, this study was conducted. The samples were 24 students who attended the Advanced Design Class. Data analysis used descriptive percentage. The research result was the students' creativity were in good criterion, $84 \%$. The implementation of portfolio needs lecturer and parents attentions.
\end{abstract}

Keywords: advance design class, creativity, portfolio

\section{INTRODUCTION}

The fashion world today, has progress rapidly. It needs personnel who are reliable in fashion designing, he/she called fashion designer. Nowadays lot of fashion designer are emerging in the world. Become a fashion designer, needs talent, creativity, and drawing skill. Each person has talent and creativity which brought when she/he was born, while skills can be obtained at school, in the community, from social media, and other. Fashion designer needs much ideas in designing new collection, must be creative. Creativity is an ability possessed by students with different levels. Creativity is a process to produce something new, it can be an idea, object in the form or sequence that produce something new (Mangihot, 2016). Creativity I ability to provide new ideas and apply them in problem solving (Munandar cite by Sit et al, 2016: 1). Creativity is ability in manifested in design or artifact including fashion (Kidd \& Workman, 1999:58). According Hurlock (cite bay Sit, at all, 2016) creativity is a person's ability to produce any composition, product or idea that is basically new and previously unknown to its maker.

There are some creative characteristics, include: happy to explore the environment, observing and holding everything; expansive and excessive exploration, his curiosity is great, likes to ask endless questions, spontaneous in expressing his thoughts and feelings, adventurous, always want to get new experiences, like to experiment, unpacking and experimenting on various things, rarely feel bored, there's just nothing to do, has a high imagination (Sit, et al, 2016:
9). Beside that characteristics, Guilford (cite by Lestari \& Budianto, 2018:242): (1) fluency, the students solving a problem by planning and showing at leats two different and correct answers, (2) flexibility, mean when the students solve the problem by planning and showing at least two defferenct ways of solving them (3) Originality means the student solving the problem by showing the way the results of their own thingking. (4) Elaboration, mean the student outlining the problem-solving steps in detail nd in detail.

Creativity can increase, it depend on the person, do they want to develop or no. The developing of creativity can be done through lots of practice and exercise, in the class or outside the class, in school or in university.

Creativity in fashion design, show of the students achievement in fashion designing, from one source, can the student create more than 5 designs?

Fashion Education Study program is one of the institution which offer some course to prepare someone to become a fashion designer, beside teacher at vocational school. This study program offer some subject, such as Fashion Design, Textile, Pattern Making, Decorating Fabrics, Creating Fabrics, Batik, Advance Design. One subject which offers how to develop fashion design is Advance Design, include how to develop the basic design to the created one, to create new collection, and portfolio as curriculum vitae. In Advanced Design subject, the students are expected to be creative. The abilities that must be mastered by students after taking the course of Design Development are: 1) The Concept of Fashion Illustration, 2) making the proportion 
of the body without measuring instruments, 3) skilled at developing designs by imitating and stylist, 4) analyzing the form of clothing from the time to the days of research, 5) compile collections, and 6) create portfolios.

The creativity increasing can be driven by an assessment model that gives students freedom to collect their work, through portfolios that are used as evaluation tools. By using portfolio tool as assessment model the students can collect their assignment. Portfolio assessment is assessing the students' work in one semester individually, at the end of the semester. The result are collected and assessed by the students themselves and by the lecturer. The students learning ability and dynamics in doing assignment by collection the works can be seen by applying portfolio. The works in the portfolio can be some essay, poems, letter, musical composition, pictures, photo, painting, book reviews/literature, research, reports, synopsis and individual real work of students obtain from their experience (Sawitri, et al 2018).

Several benefit for all of the subject in Education Fashion Portfolio provides for the teacher (Murphy and Smith, 1992: 12-13), including the teacher will concentrate on the process compare to the end of result. Sumarna $S$ and Hatta (2004: 27) showed that portfolio can be used by students to collect all documens related to knowlegde learned both in class and outside the classroom, including outside of school.

.The advantages of portfolio according Portes, Cleland, Redman (cite by Wagner, 1998) portfolio can provide the students opportunity to develop their performance, achievement, awareness, skill, and can find the gabs between their learning and strategies to develop in further. The excellence of portfolio lies in ist ability to increase students activity, because motivation can increase. The increase in motivation occcurs due to the concentration of lecture on students learning progress time to time. If the motivation increase, the creativity may increase too. These condition make students feel more valued so that their learning motivation increases. The disadvantage lies in the difficulty of equating students' environmental condition when taking grades, event though the assessment takes place over a long period of time. Weaknesses also lies in the higher cost, time and scoring needs comparing the work of one student from time to time, the lecturer also compare the results of work between students.

\section{METHOD}

By using quasi-experimental, one-shot group design, this study was conducted. The samples were 24 students who attended the Advanced Design Class. The creativity fashion design test was used to collect the data. Data analysis used descriptive percentage.

\section{RESULTS AND DISCUSSION}

The research result was the students' creativity were in good criterion, $84 \%$. It means that the implementation of portfolio is good.

During the class, the students got much assignment, which need to be done. It made the students can practice as much as they can, and they could think fluently and flexibility. The students had to create 5 new design from a part of the clothes. They also made some new designs by analyzing fashion from the past time.

The students could make many variation in developing designs, it could be increase their creativity (Figure 1). Beside of many assignment must be done, students could fine so many fashion designs from social media.

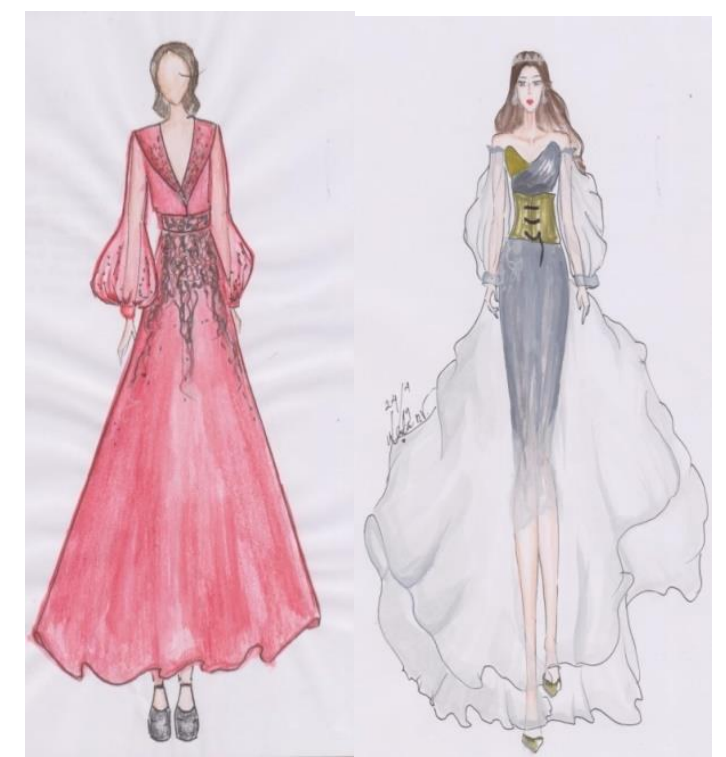

Figure 1. Students' designs

The high students' creativity, may cause of feedback from the lecturers. 
Jurnal Ilmiah Pendidikan Matematika, Volume 2/

\section{CONCLUSION}

The creativity of the students after attending the Advanced Design subject and used portfolio as the assessment tool, was $84 \%$, it was good category. It can be increased more than in the pass if they aware to be a fashion designer must have many creation for their client.

Based on the result, portfolio assessment can be applied in another subject.

\section{REFERENCES}

[1] Kidd, LK \& Workman,JE, 1999, Assesment of Creaativith in Applarel Design, Clothing and Textile researnh Journal, 17 (1) 58-64.

[2] Lestari, LB,\& Budiarto, MT. (2018). Profil Berpikir Kreatif Siswa Dalam Memecahkan Masalah Matematika Open Ended Berdasarkan Gaya Berpikir Sternberg Menurut Fungsinya,

\section{no 1 2019.(On Line)}

[3] Murphy, S and Smith MA, 1992.. Writing Portfolio. Ontario: Pippin Pu lishing Corporation.

[4] Sawitri, S. et al (2018), The Improvement of Portfolio as an Evaluation Tool on Advanced Design on Fashion Education Study Program. Engineering International Conference, Proceeding 2018

[5] Sit, M. (2016), Pengembangan Kreativitas Anak Usia Dini, Medan: Perdana Publishing (On line) (On line)

[6] Wagner, ZM. (1998), Portfolio Assessment in Vocational Education: The Assessor's View. Australian Journal of Teacher Education: Volume 23, No. 1.1998. 